\title{
BEHAVIOUR OF OLIGODENDROCYTES AND SCHWANN CELLS IN AN EXPERIMENTAL MODEL OF TOXIC DEMYELINATION OF THE CENTRAL NERVOUS SYSTEM
}

\author{
Dominguita Lühers Graça1, Eduardo Fernandes Bondan², \\ Luis Antonio Violin Dias Pereira ${ }^{3}$, Cristina Gevehr Fernandes ${ }^{4}$, Paulo César Maiorka ${ }^{5}$
}

\begin{abstract}
Oligodendrocytes and Schwann cells are engaged in myelin production, maintenance and repairing respectively in the central nervous system (CNS) and the peripheral nervous system (PNS). Whereas oligodendrocytes act only within the CNS, Schwann cells are able to invade the CNS in order to make new myelin sheaths around demyelinated axons. Both cells have some limitations in their activities, i.e. oligodendrocytes are post-mitotic cells and Schwann cells only get into the CNS in the absence of astrocytes. Ethidium bromide (EB) is a gliotoxic chemical that when injected locally within the CNS, induce demyelination. In the EB model of demyelination, glial cells are destroyed early after intoxication and Schwann cells are free to approach the naked central axons. In normal Wistar rats, regeneration of lost myelin sheaths can be achieved as early as thirteen days after intoxication; in Wistar rats immunosuppressed with cyclophosphamide the process is delayed and in rats administered cyclosporine it may be accelerated. Aiming the enlightening of those complex processes, all events concerning the myelinating cells in an experimental model are herein presented and discussed.
\end{abstract}

KEY WORDS: demyelination, remyelination, oligodendrocytes, Schwann cells, ethidium bromide, immunosuppression, cyclophosphamide, cyclosporine.

Comportamento de oligodendrócitos e células de Schwann em modelo experimental de desmielinização tóxica do sistema nervoso central

\begin{abstract}
RESUMO - Oligodendrócitos e células de Schwann realizam a produção e manutenção das bainhas de mielina, respectivamente no sistema nervoso central (SNC) e periférico (SNP). As células de Schwann, à diferença dos oligodendrócitos, são capazes de invadir o SNC para remielinizar axônios desmielinizados, sempre que os astrócitos tenham sido destruídos. O brometo de etídio é uma droga gliotóxica usada para induzir desmielinização com o desaparecimento precoce de astrócitos, de modo que as células de Schwann têm liberdade para invadir o SNC. Em ratos Wistar normais, a remielinização é detectada treze dias após desmielinização; em ratos Wistar imunossuprimidos com ciclofosfamida a reparação do tecido é tardia, enquanto que em animais tratados com ciclosporina ela é acelerada. 0 objetivo do artigo é discutir todas as etapas do processo de destruição e reparação da mielina em um modelo experimental de desmielinização em ratos.
\end{abstract}

PALAVRAS-CHAVE: desmielinização, remielinização, oligodendrócito, células de Schwamm, brometo de etídio, imunossupressão, ciclosporina, ciclofosfamida.

Oligodendrocytes and Schwann cells perform the unique task of producing and maintaining myelin sheaths around selected axons respectively in the central nervous system (CNS) and in the peripheral nervous system (PNS) ${ }^{1,2}$. Although both cells have been exhaustively investigated either in normality or in disease ${ }^{1,3}$, many questions remain unanswered concerning the proliferating capacity of oligodendro-

\footnotetext{
${ }^{1}$ Departamento de Patologia, Universidade Federal de Santa Maria (UFSM), Santa Maria RS, ${ }^{2}$ Universidade Bandeirante (UNIBAN), São Paulo, SP; ${ }^{3}$ Departamento de Histologia e Embriologia, Universidade Estadual de Campinas (UNICAMP), Campinas, SP; ${ }^{4}$ Departamento de Patologia Animal, Universidade Federal de Pelotas (UFPel), Pelotas, RS; ${ }^{5}$ Departamento de Patologia Veterinária, Universidade São Paulo (USP), São Paulo SP, Brasil.
}

Received 6 October 2000, received in final form 24 January 2001. Accepted 1 February 2001. 
cytes within demyelinating lesions $\mathrm{s}^{3-5}$ and the origin of those Schwann cells that invade the CNS to repair the lost myelin sheaths ${ }^{6-8}$. To get a deeper insight into those issues, the behaviour of both cells in variants of the Etmidium Bromide (EB) model of demyelination was studied ${ }^{6,9-13}$. EB is an intercalating gliotoxic dye extensively used to induce demyelination in the $\mathrm{CNS}^{6,7,10,13}$. The area of demyelination is larger than in other models (i.e. lysolecithin ${ }^{14}$ ) and glial cells, namely astrocytes, are destroyed early in the process. Central axons are chiefly remyelinated by Schwann cells, reflecting the degree of astrocytic damage ${ }^{14}$ and disruption of the glial limiting membrane ${ }^{15,16}$.

\section{METHOD}

Animals and ethidium bromide injection - Immunossupressed $^{9,10}$ and normal ${ }^{7}$ Wistar rats of different ages ${ }^{12,17}$ were injected with either single or multiple local doses of 0.5 to $10 \mu \mathrm{l}$ of $0,1 \%$ ethidium bromide in saline within the brainstem ${ }^{9,10,12,13}$ and the spinal cord ${ }^{6,7}$. (Table 1).

Immunosuppressive treatment - The administratiom of the immunosuppressive drugs began at the same time of the EB injection. Animals treated with cyclophosphamide (CY) had an intraperitoneal injection of two weekly doses (respectively 50 and $30 \mathrm{mg} / \mathrm{kg}$ every three days), along the length of the experiment. Animals immunosuppressed with cyclosporine (CsA) had a daily injection of $10 \mathrm{mg} / \mathrm{kg}$ in the first week and thereafter the injections were given three times a week, every 48 hours, along the length of the experiment.

Perfusions and sampling of the tissues - The rats were killed by intraaortic perfusion of $4 \%$ glutaraldehyde from $24 \mathrm{~h}$ to up to 150 days after injection in the spinal cord and from 7 to 30 days in the brainstem. Transverse slices $1 \mathrm{~mm}$ thick of the brain and the spinal cord from the area of the lesions were sampled for light and electron microscopy studies.

Processing of the samples - The samples were washed in phosphate buffer and post-fixed in Millonig's Osmium tetroxide for 2 hours. Routine dehydration and resin embedding procedures were performed ${ }^{7}$. Semi-thin sections were stained with Toluidine blue (Methilene blue) and thin sections selected from the former were stained with Uranyl acetate and Lead citrate and examined under an electron microscope.

Results - Table 1 summarizes the results which are illustrated in Figure 1.

\section{DISCUSSION}

Demyelinated lesions were induced because of the early disappearance of glial cells $s^{7,10,13,17}$. The loss of astrocytes determined a breach in the glial limiting membrane (GLM) that allowed the free entry of Schwann cells within the CNS territory ${ }^{2,7,8}$, feature reported elsewhere ${ }^{15,16}$.The bulk of the invading Schwann cells is larger than in most toxic demyelinating models where the target of the chemical is the myelin sheath itself ${ }^{14}$. In the spinal cord the number of invading Schwann cells was much more marked than in the brainstem ${ }^{8,18}$. The origin of the invading Schwann cells was not definitely sorted out. The proposed origins include the pial and cranial nerves, the dorsal roots and the sympathetic nerves that surround the blood vessels $s^{7,18}$.

In the spinal cord the GLM was restored after the recovery of astrocytes by day 13 after injection in the spinal cord $^{7}$ and by day 15 in the brainstem ${ }^{10}$. The new myelin sheaths were easily detected because of their reduced thickness related to axonal diameter $7,10,19$. The sheaths produced by Schwann cells also showed a basement membrane and collagen fibres around the cell boundaries $7,9,18$. Excluding minor differences in the morphology and timing of remyelination between the brainstem and the spinal cord, the whole process was very much alike. The burden of myelin repair was carried out by Schwann cells in areas away from the normal tissue $^{7-10}$ - chiefly in subpial and perivascular areas.

Oligodendrocytes produced the new sheaths close to the normal tissue where astrocytic processes

Table 1. Data from the rats and the experimental procedures.

\begin{tabular}{|c|c|c|c|c|c|}
\hline Number of animals & Age & Treatment & Site of the injection(s) & Euthanasia & Reference \\
\hline 22 & 19-27 days & EB (1 Inj. $1 \mu \mathrm{l} / 0.1 \%)$ & brainstem & $24 \mathrm{~h}-60$ days & 12 \\
\hline 29 & adult & EB (1 Inj. $10 \mu \mathrm{l} / 0.1 \%)$ & brainstem & $24 \mathrm{~h}-30$ days & 13 \\
\hline 20 & adult & EB $(1 \operatorname{lnj} .10 \mu \mathrm{l} / 0.1 \%)+\mathrm{CY}^{*}$ & brainstem & $24 \mathrm{~h}-30$ days & 10 \\
\hline 20 & adult & EB $(1 \operatorname{lnj} .10 \mu \mathrm{l} / 0.1 \%)+\mathrm{CsA}^{*}$ & brainstem & $24 \mathrm{~h}-30$ days & 9 \\
\hline 84 & adult & EB (1 Inj. 0.5-1 $\mu \mathrm{l} / 0.05-0.1 \%)$ & spinal cord & $24 \mathrm{~h}-270$ days & 7 \\
\hline 19 & adult & EB $(2-4$ Inj. $1 \mu \mathrm{l} / 0.1 \%)$ & spinal cord & $38 \mathrm{~h}-52$ days & 6 \\
\hline
\end{tabular}

EB, ethidium bromide; CY, cyclophosphamide; CsA, cyclosporine. *See text for details on the immunosuppressive treatment. 


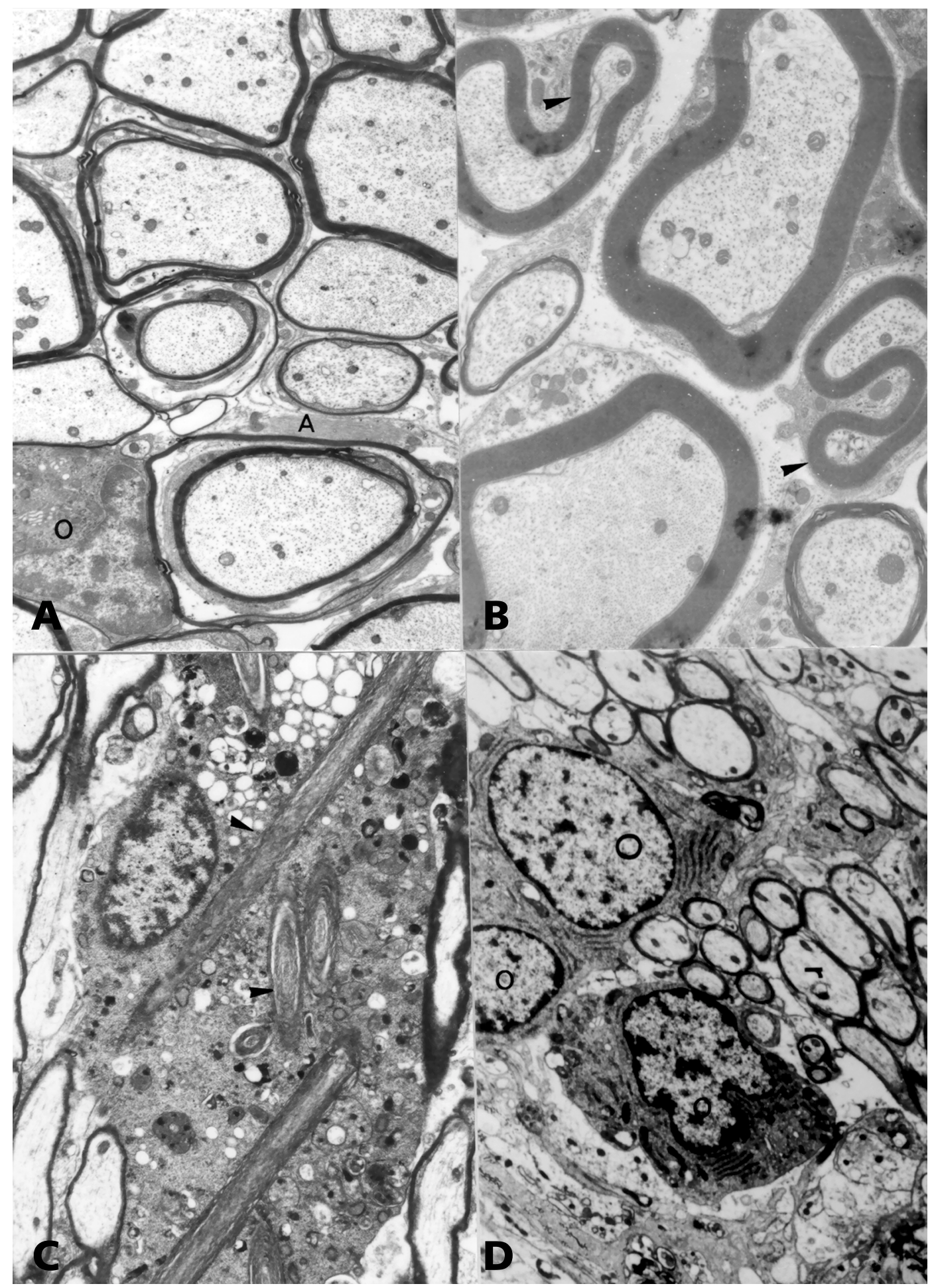

Fig 1. Ethidium bromide (EB) model of demyelination. (A) Oligodendrocytes $(O)$ remyelinate axons in an area where many astrocytic $(A)$ processes are detected. 150 days after one local injection in the spinal cord. $4500 X$. (B) Schwann cells remyelinated axons showing redundant myelin loops (arrowheads). 30 days after one local injection in the spinal cord. $4275 \mathrm{X}$. (C) Intracytoplasmic scrolls (arrowheads) in an intoxicated oligodendrocyte of a weanling rat $48 \mathrm{~h}$ after intracisternal injection of EB. 5580 X. (D) Reactive oligodendrocytes (O) 21 days after intracisternal injection in a rat treated with cyclosporine. $4875 \mathrm{X}$.

were conspicuous (Fig 1A). Oligodendrocytes showed different degrees of activation: in weanling rats they produced huge intracytoplasmic scrolls ${ }^{12}$
(Fig 1C); in normal adult rats it was detected the degree of slight activation reported in most experimental models when they repair lost myelin shea- 
ths ${ }^{10}$; in cyclosporine immunosuppressed adult rats oligodendrocytes were more conspicuous and although exhibited a round appearance, they showed a marked increase in the number of rough endoplasmic cisternae ${ }^{9}$ (Fig 1D). When cyclophosphamide was administered to the rats the whole process of removal of dead cells and disrupted myelin sheaths was delayed, suggesting an interference with macrophagic scavenging activities ${ }^{10}$.

Glial transplantation studies have shown that minor cell migration is detected when cell cultures enriched for oligodendrocytes precursors are placed within areas of normal and X-irradiated adult $\mathrm{CNS}^{20}$, a situation that mimics what is observed in the EBinduced lesions. Thus, intended transplants must be placed within the lesion area in spontaneous demyelinating diseases. In the EB-induced lesions a thin rim of oligodendrocyte remyelinated axons lined the normal tissue. Although it is known for more than a decade that totipotent neural stem cells occur in the CNS of adult mammals ${ }^{21}$ full detection of those cells has been elusive. Therefore the origin of the oligodendrocytes that remyelinated the naked axons in our model remains to be defined.

Schwann cells kept a similar behaviour despite the anatomical location and age of the rats, producing myelin for CNS axons in a fast and efficient manner, frequently forming redundant myelin loops (Fig 1B). Other than promoting axonal regeneration in the CNS Schwann cells are extremely effective in repairing areas of central demyelination and restoring conduction. They do so by their remarkably ability to produce trophic factors and cell adhesion molecules ${ }^{22}$.

In most lesions, either in the brainstem or in the spinal cord lymphocytes have been depicted. They were interpreted as part of the general inflammatory influx induced by the chemical ${ }^{11}$. Those experiments using multiple injections in the spinal cord ${ }^{23}$ confirmed the suspicion that there is no immune interference in the EB lesions. The presence of lymphocytes in the early stages of demyelination addresses these cells as a component of the whole inflammatory response that have a brief interaction with macrophages who might be the actual effector cells within the $\mathrm{CNS}^{24}$.

The EB model of experimental demyelination has been useful to demonstrate that Schwann cells are able to repair CNS axonal sheaths of myelin in any situation when astrocytes and the GLM are destroyed even when they are induced to produce their own collagen fibres ${ }^{7,8}$. Likewise it was possible to assess oligodendrocytes activation according to the age of the rats and under selective immunosuppression and also their dependence on astrocytes to produce the new myelin sheaths.

Acknowledgments - The authors are indebted to the Electron Microscopy Laboratories of the Veterinary Pathology Unit, UFSM, Santa Maria, RS, Histology and Embriology Department, UNICAMP, Campinas, SP and Department of Veterinary Pathology, FMVZ/USP, São Paulo, SP, Brazil

\section{REFERENCES}

1. Bignami A, Dahl, D. Glial cells in the central nervous system and their reaction to injury. Austin: Landes, 1994.

2. Graça DL. Mielinização, desmielinização e remielinização no sistema nervoso central. Arq. Neuropsiquiatr 1988;46:292-297

3. Norton WT. Do oligodendrocytes divide? Neurochem Res 1996;21:495-503

4. Rosano C, Felipe-Cuervo E, Wood PM. Regenerative potential of adult O1+ oligodendrocytes. Glia 1999;27:189-202

5. Tokumoto YM, Durand B, Raff MC. An analysis of the early events when oligodendrocyte precursor cells are triggered to differentiate by thyroid hormone, retinoic acid, or PDGF withdrawal. Dev Biol 1999;213:327-329

6. Gevehr FC, Graça DL, Pereira LAVD. Desmielinização e remielinização após múltiplas injeções intramedulares de brometo de etídio em ratos Wistar. Arq Neuropsiquiatr 1997;55:452-459

7. Graça DL, Blakemore WF. Delayed remyelination in rat spinal cord following ethidium bromide injection. Neuropath Appl Neurobiol 1986;12:593-605

8. Graça DL. Desmielinização tóxica do sistema nervoso central: II. Aspectos biológicos das células de Schwann observados durante o processo de reparação do tecido. Arq Neuropsiquiatr 1989;47:298-273

9. Bondan EF, Lallo MA, Graça DL. Efeitos do brometo de etídio no tronco encefálico de ratos Wistar imunossuprimidos com ciclosporina. Cadernos de Estudos e Pesquisas, UNIP 1998;IV.

10. Bondan EF, Lallo MA, Sinhorini IL, Pereira LAV, Graça DL. The effect of cyclophosphamide on brainstem remyelination following local ethidium bromide injection in Wistar rats. J Submicr Cytol Pathol 2000;32:431-438

11. Graça DL. The presence of lymphocytes in a toxically induced demyelinating process of the central nervous system. Micr Electr Biol Cell 1988;12:17-22.

12. Graça DL, Gevehr FC, Pereira LAVD. Morphological changes of myelinating oligodendrocytes in the ethidium bromide model of demyelination. Rev Esp Patol 1997;30:297-301

13. Pereira LAV, Dertkigil MSJ, Graça DL, Cruz-Höfling MA. Dynamics of remyelination in adult rat brain after exposure to ethidium bromide. J Submicr Cytol Pathol 1998;30:341-348

14. Woodruff RH, Franklin RJ. Demyelination and remyelination of the caudal cerebellar peduncle of adult rats following stereotaxic injections of lysolecithin, ethidium bromide and complement/anti-galactocerebroside: a comparative study. Glia 1999;25:216-228

15. Franklin RJ, Blakemore WF. Requirements for Schwann cells migration within CNS environments: a viewpoint. Int J Dev Neurosci 1993;11:641-649

16. Franklin RJ, Blakemore WF. Reconstruction of the glia limitans by subarachnoid transplantation of astrocyte-enriched cultures. Microsc Res Tech 1995;32:295-301

17. Graça DL. Desmielinização tóxica do sistema nervoso central: I. Efeitos de uma droga intercalante gliotóxica na medula espinhal de ratos Wistar. Arq Neuropsiquiatr 1989; 47:263-267

18. Pereira LAV, Cruz-Höfling MA, Dertkigil MSJ, Graça DL. Biology of the repair of central nervous system demyelinated lesions. Arq Neuropsiquiatr 1996;54:331-334

19. Pereira LAV, Cruz-Höfling MA, Dertkigil MSJ, Graça DL. Biology of the repair of central nervous system demyelinated lesions. Arq Neuropsiquiatr 1996;54:331-334.

20. Franklin RJ, Bayley SA, Blakemore WF. Transplanted CG4 cells (an oligodendrocyte progenitor cell line) survive, migrate, and contribute to repair areas of demyelination in X-irradiated and damaged spinal cord but not in normal spinal cord. Exp Neurol 1996;137:263-276

21. Peters A, Palay SL, Webster HF. The fine structure of the nervous system. 3Ed. New York: Oxford Univ Press 1991.

22. Bunge RP. The role of the Schwann cell in trophic support and regeneration. J Neurol 1994;241:S19-S21

23. Fernandes CG, Graça DL, Pereira LAVD. Inflammatory response of the spinal cord to multiple episodes of blood-brain barrier disruption and toxic demyelination in Wistar rats. Braz J Med Biol Res 1998;31:933-936

24. Zsuzsa F, Raine CS, Hart MN. Nervous tissue as an immune compartment: the dialect of the immune response in the CNS. Immunol Today $1994 ; 15: 218-24$ 